\title{
Effect of Performance Review and Faculty Development to Organizational Climate
}

\author{
J. M. R. Asio \\ College of Education, Arts and Sciences, Gordon College, Olongapo City, Philippines \\ E-mail: asio.johnmark@gmail.com
}

Area/Section: Business Management.

Type of the Paper: Research Paper.

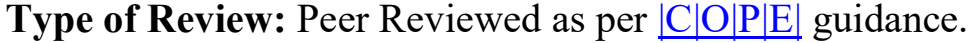

Indexed in: OpenAIRE.

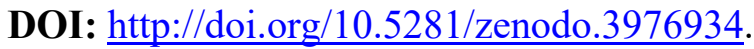

Google Scholar Citation: IJMTS.

\section{How to Cite this Paper:}

Asio, J. M. R. (2020). Effect of Performance Review and Faculty Development to Organizational Climate. International Journal of Management, Technology, and Social Sciences (IJMTS), 5(2), 1-10. DOI: http://doi.org/10.5281/zenodo.3976934.

International Journal of Management, Technology, and Social Sciences (IJMTS) A Refereed International Journal of Srinivas University, India.

(C) With Author.

\section{(c) (1) (9)}

This work is licensed under a Creative Commons Attribution-Non-Commercial 4.0 International License subject to proper citation to the publication source of the work.

Disclaimer: The scholarly papers as reviewed and published by the Srinivas Publications (S.P.), India are the views and opinions of their respective authors and are not the views or opinions of the SP. The SP disclaims of any harm or loss caused due to the published content to any party. 


\title{
Effect of Performance Review and Faculty Development to Organizational Climate
}

\author{
J. M. R. Asio \\ College of Education, Arts and Sciences, Gordon College, Olongapo City, Philippines \\ E-mail: asio.johnmark@gmail.com
}

\begin{abstract}
Faculty performance review, faculty development, and organizational climate are an essential element of the educational institution. More importantly, the mentioned variables have certain connections and interplay with each other. This study describes the performance review, faculty development, and organizational climate of a tertiary education institution. This study used a descriptive-correlation design. 56 faculties took part in the survey using a convenience sampling technique. The researcher adopted and modified an instrument and subjected it to validity and reliability test using Cronbach Alpha which yielded an overall coefficient of .0968. The statistical tools used were: mean, t-test, ANOVA, Pearson-r, and regression analysis. With the help of SPSS 20, it analyzed the gathered data. The study found that the respondents observed faculty performance review contexts. Also, the respondents agreed on the unique perspectives of faculty development. Also, the respondents see that the organizational climate affects the faculty to a great extent. There were significant differences found in the three variables. There was a direct, positive relationship between the three variables of the study. In confirmation, the performance review predicts the organizational climate of the faculty. Based on the results of the study, the researcher suggested recommendations essential for the institution, human resource, and faculty.
\end{abstract}

Keywords: Faculty Development, Performance Review, Organizational Climate, Tertiary Higher Education Institution.

\section{INTRODUCTION :}

Academic organizations play a vital role in employment. The academic organization educates the future. The employees who are part of it play an important part. Performance appraisal of employees is critical for organizational growth. We can say the same to the faculty of higher education institutions. Faculty development is also essential for both the faculty and the organization. A study mentioned that innovative leadership needs innovative thinking in the team members to ensure success in the organization and remains competitive [1]. This is true since there is already a shift in leading an organization. In the academic institution, however, it is more complex. For example, a group of researchers showed that organizational culture affects teachers' performance and motivation [2]. Another academic discussion revealed that a relationship exists between job stressors and faculty performance [3]. These ideas are vital to consider in managing the academic institution.

The performance review of individuals provides a simple glimpse of their over-all accomplishments and contributions to the organization. However, a study mentioned that rewards and reviews for faculties' outstanding contributions are nil [4]. This can be true to some institutions since financial matters are at stake and funding is necessary. However, another group of researchers suggested three recommendations to align employee development with current practices [5]. It is important to consider these minor details so that the organization satisfies its employees in academics. Parallel to this idea, a paper reported a positive impact on employee development initiatives on employee satisfaction [6]. Also, another study revealed that performance appraisal satisfaction associates with creative behavior and career development [7]. These 
positive results benefit the organization much more in academic institutions. But according to a review, after examining literature, it found that student evaluation of teaching (SET) is not an excellent choice for summative evaluation [8]. A duo proposed that the use of HR analytics negatively associates with the subjective bias in the performance appraisal system [9]. In addition, conventional evaluation methods lack assigning weight to individual criteria and rely much on numerical values [10]. Also, certain factors play a role and associated with accepting an employee in their performance appraisal [11].

A successful academic organization must have sustainable faculty development. The faculty is always in the front line of education. Thus, to help them grow and develop for this kind of profession, they need a cogent and stable faculty development. There is a relationship that exists between academic performance factors and the strategic intention of the institution [12]. Proper strategic planning creates avenues for faculty to develop and perform for the institution. A paper highlighted the importance of the faculty's professional identities as teachers and explores how faculty development programs and activities support teachers' identity [13]. In addition, a study also recommended that institutions should work towards changing the process of assessment and giving incentives to faculty work [14]. This is a reality that needs to be addressed appropriately. The faculty in return will work harder since they receive proper incentives from time to time. The lack of congruence can be detrimental in terms of work performance [15]. It is important to work aptly since the faculty serves the students and the community in a variety of ways. According to a paper, student-faculty pedagogical partnership fosters belongingness to students and staff in higher education [16]. This is an important concept to bear in mind since students in higher education are in the stage of determining who will they be in society. Finally, a researcher suggested for new faculty development approaches for long-term sustainable change [17]. Since the faculty is an indispensable piece of the workforce in the academic organization, sustaining them is very essential.

The organizational climate is an important environment for individuals to work on. Having an undesirable and unconducive work environment affects the work performance of employees. This on the other hand leads to a poor performance review from the staff and supervisors. A paper disclosed that the school environment predicts a teacher's self-efficacy [18]. Parallel to this idea, the organizational climate has a strong influence on academics' knowledge sharing [19]. Thus, the organizational climate is an environment that creates an avenue of productivity and well-being for employees. Just like what the literature mentioned, the organizational climate is the reflection of the culture and evolution of the organization [20]. On the other hand, job satisfaction has a positive impact on organizational commitment [6]. A study also demonstrated that employee resilience mediates the relationship between a learning-oriented organizational climate and proactive work behaviors [21]. In addition, a suitable organizational climate increases the level of job satisfaction of employees [22].

\section{PURPOSE OF THE STUDY :}

The purpose of this study is to describe the performance review, faculty development, and organizational climate of faculty in a tertiary education institution. Also, the study analyzes the relationship between performance review and faculty development to the organizational climate of the faculty.

The result of this study deems to be vital in the role of human resource management. This will also help in assessing the primary needs of the faculty. The academic institution can also draw important policies from the result and determine a sustainable development program for the faculty. This study will hopefully benefit the faculty primarily and help them augment their essential needs professionally and personally in the academics.

\section{METHODOLOGY :}

\subsection{Design}

This study used a descriptive-correlation design with a survey as a primary data gathering tool. Since the study aimed to describe the performance review, faculty development, and organizational climate in a higher education institution a descriptive design applies. This study also wanted to see the effect of performance review and faculty development to organizational climate, thus, the study used a correlation and regression 
analysis.

\subsection{Respondents}

There were 56 faculties that took part in the survey over two weeks' time. The study used purposive sampling technique since the study wants to study the faculty for such an occasion. The criterion to include in the study is simple, a faculty serving the institution for at least one year. However, the study excluded the part-time faculty because of the short duration of data gathering.

\subsection{Instrument}

The researcher modified an adapted instrument for this research. It has four parts. Part 1 contains the basic demographic profile of the faculty. Part 2 contains the performance review of the faculty. For part 3, it contains the faculty development status. And for the last part, it contains the organizational climate of the higher education institution. The instrument underwent reliability and validity test. After a Cronbach Alpha test, it produced an overall coefficient of .968. It also produced coefficients for the following variables: .967 for the performance review; .967 faculty development statuses; and .967 for the organizational climate. All the mentioned coefficients are higher than the benchmark score of . 70 for the acceptability and reliability of the instrument.

\subsection{Statistical Analysis}

This study used Microsoft Excel for data encoding and tabulating. The researcher used SPSS version 20 for the statistical treatment of data. For the statistical tools, this study includes weighted mean, t-test, ANOVA, Pearson-r, and Regression Analysis. The statistical tools will measure the responses of the faculty and find underlying relationships and effects between the three variables involved. This study patterned the responses of the faculty on a 5 point Likert scale.

\section{RESULTS :}

The study aims to analyze the effect of the performance review of the faculty and faculty development on the organizational climate in a tertiary education institution. The researcher analyzed the gathered data with the use of SPSS 20. This study found the following results:

Table 1. Performance Review of the Faculty

\begin{tabular}{|l|c|c|}
\hline \multicolumn{1}{|c|}{ Statements } & Mean & Description \\
\hline 1) The Performance Review effectively links pay to my performance. & 3.98 & Observed \\
\hline $\begin{array}{l}\text { 2) I have a Performance Review that clearly describes my performance } \\
\text { expectations. }\end{array}$ & 4.04 & Observed \\
\hline 3) My Performance Review is a fair reflection of my performance. & 4.05 & Observed \\
\hline $\begin{array}{l}\text { 4) In my office/department, employees are held accountable for poor } \\
\text { performance. }\end{array}$ & 4.05 & Observed \\
\hline $\begin{array}{l}\text { 5) In my office/department, employees are recognized for good } \\
\text { performance. }\end{array}$ & 4.09 & Observed \\
\hline 6) My Performance Review contains a clear employee development plan. & 3.91 & Observed \\
\hline Average Mean & $\mathbf{4 . 0 2}$ & Observed \\
\hline
\end{tabular}

Legend: 1.00-1.49= Not Observed; 1.50-2.49=Least Observed; 2.50-3.49=Moderately Observed; 3.504.49=Observed; 4.50-5.00=Very Much Observed

Table 1 presents the performance review of the faculty. As seen, statement number five got the highest mean score. This corresponds to "observed" in the Likert scale description. Statement number six got the lowest mean score. It matches to the Likert scale description of "observed". For the average mean for the performance review, it revealed a descriptive interpretation in the Likert scale of "observed". The table also means that the performance review of the faculty reflects considering different factors relevant to an excellent review. 
Table 2. Faculty Development in the Institution

\begin{tabular}{|l|c|c|}
\hline \multicolumn{1}{|c|}{ Statements } & Mean & Description \\
\hline $\begin{array}{l}\text { 1) In the past year, I have had adequate training opportunities that } \\
\text { developed my knowledge and skills. }\end{array}$ & 3.82 & Agree \\
\hline $\begin{array}{l}\text { 2) The office/department makes me aware of the available training and } \\
\text { development activities and opportunities. }\end{array}$ & 4.00 & Agree \\
\hline 3) The faculty is provided with a variety of useful training opportunities. & 3.75 & Agree \\
\hline $\begin{array}{l}\text { 4) There are career growth opportunities for me within the } \\
\text { office/department. }\end{array}$ & 4.02 & Agree \\
\hline $\begin{array}{l}\text { 5) The office/department provides me the tools and resources I need to } \\
\text { achieve my career goals. }\end{array}$ & 3.79 & Agree \\
\hline $\begin{array}{l}\text { 6) The office/department encourages continual learning and } \\
\text { development. }\end{array}$ & 4.16 & Agree \\
\hline 7) The office/department provides effective safety related training. & 4.09 & Agree \\
\hline Average Mean & $\mathbf{3 . 9 5}$ & Agree \\
\hline $\begin{array}{l}\text { Legend: } 1.00-1.49=\text { Totally Disagree; 1.50-2.49=Disagree ; 2.50-3.49=Moderately } \\
\text { 4.49ree; } 3.50-\end{array}$ \\
\hline
\end{tabular}

Table 2, shows the faculty development. As observed, statement number six got the highest mean score. The result equates to "agree" in the Likert scale description. However, statement number five got the lowest mean score. It corresponds to "agree" on the Likert description scale. All in all, the average mean score revealed the same Likert description of "agree" in the scale. This means that the faculty observe and sustain substantial professional development. They also apply these professional development activities in their practice of the profession.

Table 3. Organizational Climate of Faculty

\section{Statements}

1) I believe that discipline is administered fairly and consistently to all employees in the office/department.

2) Discipline in the office/department is administered according to Civil Service Rules.

3) As an employee, I feel secure in speaking up about the office/department practices and/or policies that are ethically questionable.

4) My co-workers know the difference between ethical and unethical behaviors, and seem to care about the differences.

5) The office/department is serious about maintaining a work environment that is free of violence and harassment

6) The office/department is serious about maintaining a work environment that is free of drugs and alcohol.

7) The office/department creates and maintains a safe and healthy work environment by taking action which prevents injury or harm to self, others, equipment and/or property.

\section{Average Mean}

\begin{tabular}{|c|c|}
\hline Mean & Description \\
\hline 4.09 & Great Extent \\
\hline 4.13 & Great Extent \\
\hline 4.02 & Great Extent \\
\hline 4.11 & Great Extent \\
\hline 4.43 & Great Extent \\
\hline 4.50 & Very Great Extent \\
\hline 4.50 & Very Great Extent \\
& \\
\hline $\mathbf{4 . 2 5}$ & Great Extent \\
\hline
\end{tabular}

Legend: 1.00-1.49= Very Low Extent; 1.50-2.49=Low Extent; 2.50-3.49=Moderate Extent; 3.50-4.49=Great Extent; 4.50-5.00= Very Great Extent

In table 3, it displays the organizational climate of faculty in the institution. As reflected, statements number six and seven got the highest mean scores. They correspond to a "very great extent" in the Likert scale description. Statement number three gained the lowest mean score. It equates to a "great extent" in the Likert scale description. Overall, the average mean score showed a Likert scale description of "great extent". The 
result means that the organizational climate affects the faculty to a variety of degrees. This helps them grow in the institution.

Table 4. Significant Differences on the Responses of the Faculty

\begin{tabular}{|c|c|c|c|c|}
\hline & $n$ & Performance & Development & Climate \\
\hline $\begin{array}{l}\text { Sex } \\
\text { Male } \\
\text { Female }\end{array}$ & $\begin{array}{l}25 \\
31 \\
\end{array}$ & $\begin{array}{l}1.799 \\
(.078)\end{array}$ & $\begin{array}{l}1.477 \\
(.145)\end{array}$ & $\begin{array}{l}0.760 \\
(.450)\end{array}$ \\
\hline $\begin{array}{l}\text { Civil Status } \\
\text { Single } \\
\text { Married }\end{array}$ & $\begin{array}{l}45 \\
11\end{array}$ & $\begin{array}{c}2.343^{*} \\
(.023)\end{array}$ & $\begin{array}{l}0.813 \\
(.420)\end{array}$ & $\begin{array}{c}3.332 * \\
(.002)\end{array}$ \\
\hline $\begin{array}{l}\text { Employment Status } \\
\text { Regular } \\
\text { Contract of Service (COS) }\end{array}$ & $\begin{array}{c}9 \\
47\end{array}$ & $\begin{array}{c}-3.267^{*} \\
(.002)\end{array}$ & $\begin{array}{c}-2.519 * \\
(.015)\end{array}$ & $\begin{array}{c}-3.737^{*} \\
(.000)\end{array}$ \\
\hline $\begin{array}{l}\text { Salary } \\
15,000-20,000 \text { pesos } \\
21,000-30,000 \text { pesos }\end{array}$ & $\begin{array}{l}46 \\
10\end{array}$ & $\begin{array}{l}3.123 * \\
(.003)\end{array}$ & $\begin{array}{c}2.370^{*} \\
(.021)\end{array}$ & $\begin{array}{c}3.794 * \\
(.000)\end{array}$ \\
\hline $\begin{array}{l}\text { Age } \\
21-30 \text { years old } \\
31-40 \text { years old } \\
41-50 \text { years old } \\
51 \text { years old above }\end{array}$ & $\begin{array}{c}35 \\
13 \\
4 \\
4\end{array}$ & $\begin{array}{l}1.856 \\
(.149)\end{array}$ & $\begin{array}{l}0.252 \\
(.859)\end{array}$ & $\begin{array}{l}5.199 * \\
(.003)\end{array}$ \\
\hline $\begin{array}{l}\text { Educational Attainment } \\
\text { College Graduate } \\
\text { Post Graduate Level } \\
\text { Post Graduate }\end{array}$ & $\begin{array}{c}26 \\
24 \\
6\end{array}$ & $\begin{array}{l}4.373^{*} \\
(.017)\end{array}$ & $\begin{array}{l}4.998^{*} \\
(.010)\end{array}$ & $\begin{array}{l}6.950^{*} \\
(.002)\end{array}$ \\
\hline $\begin{array}{l}\text { Years in Service } \\
1-5 \text { years } \\
6-10 \text { years } \\
11-15 \text { years }\end{array}$ & $\begin{array}{c}38 \\
11 \\
7\end{array}$ & $\begin{array}{l}6.374^{*} \\
(.003)\end{array}$ & $\begin{array}{l}2.208 \\
(.120)\end{array}$ & $\begin{array}{c}11.213^{*} \\
(.000)\end{array}$ \\
\hline
\end{tabular}

Table 4 presents the significant differences in the faculty's response. As seen, there are no significant differences in the performance review, faculty development, and organizational climate when grouped according to sex. Since the following $t$-values of 1.799 (performance review), 1.477 (faculty development), and 0.760 (organizational climate) correspond to $p$ values higher than the Alpha significance level of .05. In terms of civil status, we observe significant differences in a performance review with $a t$-value of 2.343 and an organizational climate with $a t$-value of 3.332. The results correspond to $p$ values lower than the Alpha level of significance of .05. In terms of employment status, there are significant differences also found with $t$ values of -3.267 (performance review), -2.519 (faculty development), and -3.737 (organizational climate). All results have $p$-values lower than the .05 Alpha significance level. In terms of salary, significant differences also exist. The following $t$-values of 3.123 (performance review), 2.370 (faculty development), and 3.794 (organizational climate) reflected $p$-values lower than the .05 Alpha significance level. In terms of age, only the organizational climate showed a significant difference with the $F$-value of $5.199, p<.05$. In terms of educational attainment, the following $F$-value of 4.373 (performance review), 4.998 (faculty development), and 6.950 (organizational climate) correspond to $p$-values lower than the .05 Alpha significance level. For the last item, years in service, performance review ( $F$-value: 6.374), and organizational climate ( $F$-value: 11.213$)$ got significant differences since their respective probability values are lower than the alpha .05 level of significance. The abovementioned result means we observe a certain variance in opinion. This is so since there are different variables involved in the analysis. 
Table 5. Correlation Matrix between Performance Review, Faculty Development, and Organizational Climate

\begin{tabular}{|l|c|c|c|}
\hline \multicolumn{1}{|c|}{ Variables } & 1 & 2 & 3 \\
\hline 1) Performance Review & 1 & & \\
\hline 2) Faculty Development & $\begin{array}{l}.662^{*} \\
(.000)\end{array}$ & 1 & \\
\hline 3) Organizational Climate & $.711^{*}$ & $.472^{*}$ & 1 \\
& $(.000)$ & $(.000)$ & \\
\hline
\end{tabular}

$* p<.05$

Table 5 shows the correlation matrix between performance review, faculty development, and organizational climate. As seen, there is a significant relationship between performance review, faculty development, and organizational climate. The following r-values of .711 (performance review) and .472 (faculty development) show a direct positive relationship to organizational climate. The result means that performance review and faculty development affect the organizational climate of the institution. Besides, in every unit of increase in the performance review and faculty development, there is also an increase in organizational climate.

Table 6. Effects of Performance Review and Faculty Development to Organizational Climate

\begin{tabular}{|l|c|c|c|c|c|}
\hline & \multicolumn{2}{|c|}{$\begin{array}{c}\text { Unstandardized } \\
\text { Coefficients }\end{array}$} & $\begin{array}{c}\text { Standardized } \\
\text { Coefficients }\end{array}$ & t-value & Sig. \\
\hline Model & $\mathrm{B}$ & Std. Error & Beta & & \\
\hline 1 Constant) & 1.923 & .339 & & 5.679 & .000 \\
\hline Performance Review & .577 & .105 & .710 & $5.510^{*}$ & .000 \\
\hline Faculty Development & .002 & .099 & .003 & .021 & .983 \\
\hline
\end{tabular}

Note: Constant $=1.923, F(2,53)=27.147,{ }^{*} p<.05, \mathrm{R}^{2}=.506$

Table 6 specifies the effects of performance review and faculty development to organizational climate. As shown, we can claim that performance review yielded a B coefficient lower than the .05 Alpha significance level. This only means that performance review is a significant predictor of organizational climate in the institution.

The regression model with its two predictors produced $\mathrm{R} 2=.506, F(2,53)=27.147, p<.05$. As seen further in the table, performance review produced a positive regression weight, showing that if you have a positive performance review the better the organizational climate. Faculty development also correlated, but not to a significant extent. This means that faculty development also accounts for the organizational climate of the institution.

\section{DISCUSSION :}

The study aims to analyze the performance review, faculty development, and organizational climate of selected faculty in a tertiary education institution. It also looks into the impact of performance review and faculty development on the organizational climate of the institution.

Based on the result of the study, in terms of performance review, the respondents observed all the mentioned statements mentioned in the survey. This means that there is faculty awareness regarding performance reviews. Concerning this, a study explained that there is top-level organizational happiness by jobs with a lofty performance standard [23]. Additionally, performance appraisal of teaching faculty challenges with the new role of teachers [10].

In terms of faculty development, the respondents have a consensus of "agree" in all the statements mentioned. Developing a faculty professionally and personally is essential in an institution. It has a tremendous effect on the productivity of the faculty which benefits the institution. Parallel to this result is a study that showed the faculty measured competencies influence students' perceptions in higher education [24]. However, outputs 
and metrics reward faculty work targeted the academics and disregard public dimensions [14]. Didactic culture affects the teaching performance of professors [25].

From the perspective of respondents towards organizational climate, the consensus resulted to a great extent. Meaning to say, the institution is particular in providing the ideal work environment to all faculties. Another study showed that the organizational climate and work style compliment the relationship between leadership style and job satisfaction [22]. Also, organizational climate and information technology influence competitiveness [26].

The study also underwent a series of statistical inference to determine significant differences in the opinion of the respondents. The study revealed some interesting findings. All three variables generated contrasting results which led to significant differences. Also, a strong positive relationship existed between the three variables. This means that the study fulfilled its primary goal. The performance review and faculty development affect the organizational climate of faculty. However, organizational climate also harms teacher motivation and performance [2]. To justify the extent of the relationship between the three variables, a regression analysis satisfies the result. The study found that performance review predicts the organizational climate of faculty. Faculty perceived a multi-source method of evaluating (MME) teaching performance as a useful tool, however, they still believe that MME produces a summative product than a formative process [27]. Besides, institutions need to plan strategies to maintain low levels of stress for faculty for better performance [3]. Faculty developers should reframe workshops and focus on the scope of the journey of faculty development [17]. This will hopefully have a positive effect on commitment and a negative effect on turnover intention [28].

\section{CONCLUSIONS :}

Based on the result of the study, the researcher concluded that: the institution "observed" the context of the performance review of the faculty. The faculty also "agreed" on the unique aspects of development in the institution. Also, the organizational climate affects the faculty to a "great extent". There are significant differences observed in performance review (civil status, employment status, educational attainment, salary, and years in service); faculty development (employment status, salary, and educational attainment); and organizational climate (civil status, employment status, age, salary, educational attainment, and years in service). Also, there is a significant relationship between performance review, faculty development, and organizational climate. The study also found that performance review is a substantial predictor of organizational climate.

\section{RECOMMENDATIONS :}

Based on the results of the study, the researcher suggests the following to the institution, human resource management, and the faculty. First, the human resource management department should provide better and more reliable performance review tools that will reflect the actual contribution of every faculty in the institution. Second, a performance-based reward and incentive program for the deserving faculty should be instituted. Third, a sustainable faculty development plan for every faculty member in the institution. Fourth, commitment and trust among the faculty in the institution. Fifth, the institution should provide a more conducive work environment for the faculty members.

\section{REFERENCES:}

[1] Osman, N. W., \& Kamis, A., (2019). Innovation leadership for sustainable organizational climate in institution of technical and vocational education and training (TVET) in Malaysia. Asian Journal of Assessment in Teaching and Learning, 9 (1), 57-64. https://doi.org/10.37134/ajatel.vol9.no1.6.2019

[2] Rivai, Gani, M. U., \& Murfat, M.Z. (2019). Organizational culture and organizational climate as a determinant of motivation and teacher's performance. Advances in Social Sciences Research Journal, 6 (2), 555-566. https://oi.org/10.14738/assri.62.6267 
[3] Mwenda, F. K., Kiflemarian, A., \& Kimani, S.W. (2019). An assessment of the relationship between job stressors and faculty performance in selected private universities in Kenya. International Journal of Education and Research, 7(7), 45-56.

[4] Vedhathiri, T. (2020). Faculty performance improvement through effective human resource management practices. Journal of Engineering Education Transformations, 33, 18-34.

[5] Dachner, A. M., Ellingson, J. E., Noe, R. A., \& Saxton, B. M. (2019). The future of employee development. Human Resource Management Review, 100732. https://doi.org/10.1016/j.hrmr.2019.100732

[6] Jehanzeb, K., \& Mohanty, J. (2018). Impact of employee development on job satisfaction and organizational commitment: person-organization fit as moderator. International Journal of Training and Development, 22(3), 171-191. https://doi.org/10.1111/ijtd.12127

[7] Ismail, H., \& Rishani, M. (2018). The relationships among performance appraisal satisfaction, career development and creative behavior. The Journal of Developing Areas, 52 (3), 109-124. https://doi.org/10.1353/jda.2018.0040

[8]_Horstein, H. A. (2017). Student evaluations of teaching are an inadequate assessment tool for evaluating faculty performance. Cogent Education, 4, 1304016. https://dx.doi.org/10.1080/2331186X.2017.1304016

[9] Anshu, S., \& Tanuja, S. (2017). HR analytics and performance appraisal system: A conceptual framework for employee performance. Management Research Review, 40 (6), 684-697. https://doi.org/10.1108/MRR$\underline{\text { 04-2016-0084 }}$

[10] Mamatha G., Sridhar, R., \& Balasubramanian, S. (2016). Fuzzy logic as a tool for evaluation of performance appraisal of faculty in higher education institutions. SHS Web of Conferences, 26, 01121. https://doi.org/10.1051/shsconf/20162601121

[11] Kim, T., \& Holzer, M. (2016). Public employees and performance appraisal: A study of antecedents to employees' perception of the process. Review of Public Personnel Administration, 36 (1), 31-56. https://doi.org/10.1177/0734371X14549673

[12] Aljawarneh, N. M., al-Bourini, F. A., Bourini, I., Almaaitah, M. F., \& Alomari, K.A. (2020). Directing strategic decision and perceived faculty performance using PLS analysis and Monte Carlo simulation in Jordanian private universities. Talent Development \& Excellence, 12 (3), 2235-2252.

[13] Steinert, Y., O’Sullivan, P.S., \& Irby, D.M. (2019). Strengthening teachers' professional identities through faculty development. Academic Medicine, 94(7), 963-968. https://doi.org/10.1097/ACM.0000000000002695

[14] Alperin, J.P., Niewves, C.M., Schimanski, L.A., Fschman, G.E., Niles, M.T., \& McKiernan, E.C. (2019). How significant are the public dimensions of faculty work in review, promotion and tenure documents? eLife, 8, e42254. https://doi.org/10.7554/eLife.42254

[15]_Nerstad, C.G.L., Dvsvik, A., Kuvaas, B., \& Buch, R. (2018). Negative and positive synergies: On employee development practices, motivational climate, and employee outcomes. Human Resource Management, 57 (5), 1285-1302. https://doi.org/10.1002/hrm.21904

[16] Sather, B.M., \&Felten, P. (2017). Where students engagement meets faculty development: how studentfaculty pedagogical partnership fosters a sense of belonging. Student Engagement in Higher Education Journal, 1(2), 3-11.

[17] Dewsbury, B.M. (2017). On faculty development of STEM inclusive teaching practices. FEMS Microbiology Letters, 364, 1-6. https://doi.org/10.1093/femsle/fnx179 
[18] Woolfson, L., \& Durkin, K. (2020). School environment and mastery experience as predictors of teachers' self-efficacy beliefs towards inclusive teaching. International Journal of Inclusive Education, 24(2), 218-234. https://doi.org/10.1080/13603116.2018.1455901

[19] Al-Kurdi, O.F., El-Haddadeh, R., \& Eldabi, T. (2020). The role of organizational climate in managing knowledge sharing among academics in higher education. International Journal of Information Management, 50, 217-227. https://doi.org/10.1016/j.ijinfomgt.2019.05.018

[20] Isac, N. (2020). The impact of elementary work unit (EWU) on the organizational climate. Ecoforum, 9 (1), 21-25.

[21] Caniels, M.C.J., \& Baaten, S.M.J. (2018). How a learning-oriented organizational climate is linked to different proactive behaviors: The role of employee resilience. Social Indicators Research, 143, 561-577.

[22] Moslehpour, M., Altantsetseg, P., Mou, W., \& Wong, W.K. (2018). Organizational climate and work style: The missing links for sustainability of leadership and satisfied employees. Sustainability, 11, 125. https://doi.org/10.3390/su11010125

[23] Pincheira, F.J.D., \& Garces, M.E. C. (2018). Effects of organizational climate and psychosocial risks on happiness at work. Contaduria y Administracion, 63 (4), 1-14. https://dx.doi.org/10.22201/fca.224488410e.2018.1142

[24] Malechwanzi, J.M., Lei, H., \& Wang, L. (2016). Students' percetions an faculty measured competencies in higher education. International Journal of Higher Education, 5(3), 56-69. https://doi.org/10.5430/ijhe.v5n3p56

[25]_Fontanini, C.A.C. (2017). The didactic culture in the faculty performance in higher education: The case of a business school in Brazil. Creative Education, 8, 1236-1259. https://doi.org/10.4236/c.2017.88088

[26] Maulani, G.A.F., \& Hamdani, N.A. (2019). The influence of information technology and organizational climate on the competitiveness of private universities in Indonesia. International Journal of Recent Technology and Engineering, 8(1S), 142-146.

[27] Lyde, A.R., Grieshaber, D.C., \& Byrns, G. (2016). Faculty teaching performance: Perceptions of a multisource method for evaluation (MME). Journal of the Scholarship of Teaching and Learning, 16 (3), 82-94. https://doi.org/10.14434/josotl.v16i3.18145

[28] Puspitawati, N.M.D., \& Atmaja, N.P.C.D. (2019). The role of organizational commitment mediating organizational climate with turnover intention. International Journal of Applied Business \& International Management, 4 (3), 23-32.

$* * * * * * * * * * *$ 